\title{
REVOLUSI DIGITAL \& DINAMIKA PERKEMBANGAN CRYPTOCURRENCY DITINJAU DARI PERSPEKTIF LITERATUR REVIEW
}

\author{
Uli Wildan Nuryanto ${ }^{1}$, Pramudianto ${ }^{2}$ \\ ${ }^{1,2}$ Program Studi Magister Manajemen Universitas Bina Bangsa \\ uli.wildan11@gmail.com
}

\begin{abstract}
ABSTRAK
Perkembangan teknologi digital yang semakin cepat dan berpengaruh signifikan terhadap seluruh dimensi kehidupan manusia, salah satunya berpengaruh kepada sektor finansial. Kehadiran cryptocurrency dengan menggunakan teknologi blockchain telah merubah sistem keuangan yang selama ini dipakai serta melahirkan pro dan kontra. Sistem yang dibangun dengan menggunakan peer-to-peer menyebabkan sektor keuangan tidak lagi berpusat pada satu otoritas yang mengendalikan keuangan. Sifat cryptocurrency yang dibuat menyerupai karakteristik emas seperti jumlahnya yang terbatas, cara mendapatkannya harus ditambang, lebih tahan terhadap inflasi membuat minat masyarakat dipenjuru dunia meningkat signifikan. Sistem kerja blockchain yang desentalisasi, anonym dan aman telah menghadirkan paradigma baru disektor keuangan. Namun disisi lain banyak tantangan dan dinamika yang muncul akibat munculnya cryptocurrency, salah satunya adalah risiko dilihat dari sisi legalitas dimana terdapat kasus pencucian uang yang melibatkan penggunaan crypto, kerugian investor atau konsumen akibat proses ICO yang tidak berjalan mulus, timbulnya kerugian dari crypto exchanges yang dapat diretas sehingga saldo dompet digital nasabah terkuras. Nilai crypto yang cenderung memiliki volatilitas tinggi dan fluktuasi yang cepat ikut meningkatkan risiko. Kesiapan negara-negara dalam mempertimbangkam dan mengkaji undangundang terkait penggunaan crypto menjadikan kontribusi dalam penelitian ini. Salah satu minat terbesar masyarakat adalah penggunaan crypto sebagai asset jangka panjang, yang nilainya meningkat dari tahun ke tahun. Bahkan Bitcoin sebagai salah satu mata uang crypto paling terkenal sebelumnya tidak bernilai namun saat ini memiliki nilai yang sangat fantastis dan menjadi incaran banyak investor.
\end{abstract}

Kata Kunci: Revolusi Digital, Blockchain, Cryptocurrency, Peluang \& Risiko Crypto

\begin{abstract}
The spread of digital technology currently faster and influence on all of human dimension, including to the financial sector. The presence of cryptocurrency using blockchain technology has changed the previously system that has been used for a long period and it come a pros and cons. The system built using peer-to-peer cause the system no longer need the $3^{\text {rd }}$ party that control the financial system and since the system decentralized. The nature of cryptocurrency which made as the same with gold characteristic such as the limitation of quantity, process to get it must through the mining process, more resistance from inflation are making people and society interested and significantly increase time by time. The decentralized and anonymous blockchain working system for token holders and safe has presented as a new paradigm in the financial sector. But on other hand, there are many challenges and dynamics that arise due to the emergence of these cryptocurrency, one of which is risk from the legal perspective where there are cases of money laundering involving of crypto, losses to the investor asset due to ICO process that not run smoothly, the emergence losses from crypto exchanges that hacked due to not have a high security backup system that made the customer losses their digital wallet. Crypto value that tend to have high volatility and fluctuating rates with fast count also increase the risk. The readiness of countries and drafting laws related to the crypto was contribution for this research. One of the biggest interested from the public is the use of crypto as long asset investment, where the values increasing from year to year, even Bitcoin as one of the
\end{abstract}


cryptocurrencies that previously worthless but currently has very fantastic values and become a favourite from the investor.

Keywords: Digital Revolution, Blockchain, Cryptocurrency, Risk and Opportunity

\section{PENDAHULUAN}

Perkembangan teknologi digital yang semakin cepat telah menciptakan sebuah lompatan besar secara global yang sangat fundamental dan melahirkan inovasi secara besar-besaran serta berdampak luas terhadap tatanan kehidupan manusia serta mendorong terjadinya disrupsi digital. Kita dapat melihat secara langsung saat ini bahwasanya sebuah platform digital mampu merubah sebuah proses produksi, supply chain dan iklan di media yang menyebabkan banyaknya perusahaan media bertumbangan sehingga mau tidak mau melakukan adaptasi dan mengubah model bisnisnya.

Teknologi tidak hanya dapat dilihat dari satu dimensi saja, perkembangan yang semakin cepat saat ini juga telah berkontribusi positif bagi kehidupan manusia. Perkembangan teknologi saat ini tidak hanya bisa dilihat dari sisi ilmu alam atau ilmu rekayasa sebagai sebuah artefak pasif, akan tetapi teknologi dan manusia berinteraksi secara aktif, sehingga sudah sepatutnya dilihat dari sisi perspektif dinamika sosioteknis (Guston et al, 2014). Dinamika dan interaksi yang terjadi secara aktif antara teknologi dan manusia akibat revolusi industri terjadi pada ruang lingkup kolektif manusia yang terdiri dari banyak aktor, dibangun antara sebab dan akibat yang sangat kompleks dimana meliputi dimensi ekonomi, sosial, budaya, politik dan etika serta menghasilkan efek yang sulit untuk diprediksi di masa yang akan datang.

Berkaitan dengan Revolusi Industri 4.0 yang menjadi lompatan besar dalam perkembangan teknologi adalah dengan berkembangnya big data, kecerdasan buatan (artificial intelligence-AI), blockchain, dan teknologi finansial (fintech). Secara umum, teknologi tersebut bukanlah sebuah teknologi yang baru, namun telah lahir beberapa decade yang lalu, akan tetapi pada beberapa tahun terakhir teknologi tersebut telah mengalami lompatan besar dan membawa perubahan yang sangat drastis kepada kehidupan manusia yang berdampak langsung terhadap dimensi sosial ekonomi, yang belum pernah terbayangkan sebelumnya. Suka atau tidak suka, pada kenyataannya saat ini banyak aspek dari kemajuan teknologi pada revolusi industri 4.0 telah menjadi cikal bakal bagi lahirnya revolusi radikal di berbagai bidang, seperti transportasi, transaksi jual beli, komunikasi dan pemerintahan. Bahkan perkembangan teknologi finansial telah menjamur diberbagai kota besar di Indonesia akibat dari perkembangan blockchain.

Revolusi industri 4.0 dikenal juga sebagai transformasi digital yang secara global telah memunculkan sebuah tren baru yang dikenal dengan Internet of Things (IoT) yang memanfaatkan internet sebagai infrastruktur yang menghubungkan benda fisik dengan jaringan virtual secara berkesinambungan yang berperan aktif dalam proses bisnis. Diantara kemajuan teknologi ini adalah 
Prosiding The 1st National Conference on Applied Business, Education, \& Technology (NCABET)"

Unversitas Bina Bangsa 2021

DOI Article : $10.46306 /$ ncabet.v1i1.22

munculnya sistem pembayaran secara digital dengan menggunakan cryptocurrency atau lebih dikenal dengan mata uang digital yang menggunakan teknologi chryptography (kriotograpi) dimana crypt berarti tersembunyi dan graph berarti tulisan. Teknik kriptograpi merupakan suatu teknik yang mampu menyampaikan pesan secara sembunyi dengan memanfaatkan fitur enskripsi data untuk keamanan data saat mengakses informasi pada jaringan internet, sehingga data tersebut akan menjadi lebih aman dari peluang peretasan informasi oleh pihak yang tidak bertanggung jawab.

Teknik kriptograpi bukanlah hal yang baru, namun telah dipergunakan sejak ribuan tahun silam. Seperti halnya Raja Julius Caesar menggunakan teknik ini untuk berkomunikasi dengan jenderal-jenderalnya melalui sandi klasik yang menggunakan huruf atau kata dengan huruf atau kata substitusi lainnya sehingga lawan tidak akan mampu membaca dan mengartikannya. Alat bantu yang digunakan untuk memindahkan sandi berbeda-beda, pada zaman Yunani digunakan scytale yang merupakan alat bantu untuk memindahkan sandi. Pada abad ke 19 banyak ditemukan alat mekanik enkripsi atau deskripsi yang digunakan seperti misalnya disk sandi milik Alberti, silinder multi Thomas Jefferson, dan tabula recta Johanner trithemius. Sedangkan pada abad ke-20 alat enskripsi atau deskripsi yang digunakan seperti mesin rotor yang diberi nama mesin Enigma yang pada saat itu digunakan oleh militer Jerman selama perang dunia II.

Dengan perkembangan revolusi industri 4.0 saat ini dimana komputer telah berkembang dengan pesat dan juga didukung dengan ketersediaan akses internet yang begitu cepat telah membawa lompatan besar bagi Teknik kriptograpi pada era modern saat ini dapat mengenkripsi setiap jenis data yang mungkin dalam bentuk biner tidak seperti chipper klasik yang hanya mengenkripsi teks bahasa tertulis saja sehingga mendorong bagi kemajuan teknik kromatograpi. Dalam era modern saat ini dikenal 3 jenis metode kriptograpi antara lain symmetric key cryptography, public key cryptography dan hash function. Perkembangan pesat kriptograpi ini telah melahirkan sebuah teknologi blockchain, dimana setiap block nya terdiri atas hash kriptograpi dari blok sebelumnya, timestamp dan data transaksi yang resisten terhadap modifikasi data

Blockchain merupakan buku besar yang terdistribusi (distributed ledger) yang terbuka dan mencatat transaksi antara dua belah pihak dan dapat diverifikasi secara permanen. Blockchain dikelola dengan menggunakan jaringan peer-to-peer secara kolektif dengan menggunakan protokol tertentu sehingga setelah data direkam maka tidak akan dapat diubah tanpa perubahan pada blok-blok selanjutnya yang membutuhkan konsensus banyak jaringan atau terdesentralisasi. Blockchain pertama kali diciptakan oleh Satoshi Nakamoto pada tahun 2008 yang dimanfaatkan sebagai buku besar untuk transaksi publik Cryptocurrency Bitcoin, sehingga menjadikannya sebagai mata uang digital pertama yang mampu mengatasi permasalahan pembayaran ganda tanpa memerlukan otoritas secara sentral, serta mengilhami aplikasi uang digital lainnya. 
Penelitian ini menawarkan beberapa kontribusi. Pertama adalah mengupas tuntas sejarah perkembangan cryptocurrency. Kedua membahas detail jenis-jenis cryptocurrency serta perkembangan jumlahnya dari tahun ke tahun. Ketiga fluktuasi cryptocurrency dari tahun ketahun. Keempat Penggunaan cryptocurrency dan pro-kontra penggunaan cryptocurrency. Kelima adalah regulasi internasional tentang penggunaan cryptocurrency diberbagai negara.

\section{METODE PENELITIAN}

Penelitian ini menggunakan metodologi tinjauan literatur naratif yang merupakan pendekatan penelitian yang bertujuan untuk melakukan pemahaman dan kajian intensif terhadap fenomenda dan pengetahuan yang relevan dengan topik dan berpotensi untuk menutupi kelemahan konsep atau teori yang layak untuk dilakukan penelitian lebih lanjut. Dengan tujuan menekankan deskripsi terhadap fenomena cryptocurrency sebagai salah satu pengaruh kemajuan teknologi digital saat ini, sehingga didapatkan pemahaman yang luas dan mendalam terhadap fenomena tersebut dengan menggunakan library research atau penelitian kepustakaan terhadap literatur-literatur kepustakaan dan dokumen penelitian sebelumnya.

\section{HASIL DAN PEMBAHASAN}

\section{Latar Belakang dan Sejarah Kemunculan Cryptocurrency}

Cryptocurrency merupakan bagian dari mata uang digital yang menggunakan jaringan tidak tersentralisasi atau biasa dikenal dengan desentralisasi, sehingga cryptocurrency tidak memiliki institusi terpusat dalam pengontrolannya. Cryptocurency merupakan jenis mata uang digital yang dihasilkan dari algoritma kriptograpi dan dipertukarkan dengan menggunakan jaringan internet dan menggunakan protokol seperti jaringan peer-to-peer (Nakamoto, 2008). Cryptocurrency sangat berbeda jika dibandingkan dengan uang fiat yang saat ini kita gunakan. Dimana uang fiat memiliki bentuk kertas dan logam yang menjadi alat pembayaran yang sah dan diterima oleh masyarakat dalam transaksi jual beli sehari-hari. Uang fiat juga dikeluarkan oleh masing-masing Bank Sentral yang dimiliki di oleh masing-masing negara sehingga Bank Sentral memiliki hak oktroi dalam mencetak dan menyebarkan uang kartal.

Kemunculan cryptocurrency tidak dapat dilepaskan dari krisis finansial global yang terjadi pada tahun 2008, dimana kepercayaan masyarakat terhadap sistem perbankan konvensional menjadi perhatian setelah tanda gejolak ekonomi muncul pada bulan maret tahun 2008 saat Bear Stearns dan lehman Brother dinyatakan bankrut. Bear Stearns merupakan sebuah bank investasi global dan perusahaan perdagangan sekuritas yang berbasis di New York yang pada tahun 2008 dinyatakan bangkrut dan kemudian dijual kepada JPMorgan Chase. Sedangkan Lehman Brother merupakan bank 
Prosiding The 1st National Conference on Applied Business, Education, \& Technology (NCABET)"

Unversitas Bina Bangsa 2021

DOI Article : 10.46306/ncabet.v1i1.22

investasi terbesar keempat di Amerika yang bergerak di bidang investasi, penjualan dan perdagangan saham dan obligasi namun pada tahun 2008 bernasib sama seperti Bear Stearns dinyatakan pailit, sehingga asetnya terpaksa dijual kepada Barclays dan Nomura Holdings. Hal tersebut menimbulkan terjadinya kebangkrutan terbesar dalam sejarah Amerika Serikat sehingga memicu krisis keuangan global 2008.

Krisis tersebut menjalar ke berbagai negara dibelahan dunia lainnya seperti Eropa dan Asia. Di Eropa, Negara maju seperti Finlandia mengalami penurunan produksi industri, investasi swasta, dan ekspor (Soderlund \& Kekkonen, 2014). Sedangkan di Negara China, banyak lembaga keuangan dan bank asing yang ditangguhkan hingga kemudian berhenti merekrut staff (Velazquez, 2010). Banyak Bank yang mengalami kekurangan likuiditas akibat menggunakan pinjaman pasar jangka pendek tanpa jaminan atau agunan (Milne, 2018). Hal tersebut berdampak terhadap reputasi bank dan lembaga keuangan lainnya seperti perusahaan asuransi pada tingkat global mengalami penurunan dimata masyarakat dunia.

Setelah terjadinya krisis finansial yang melanda dunia, munculah seseorang dengan nama samaran 'Satoshi Nakamoto', ada juga yang menyebutkan bahwasanya 'Satoshi Nakamoto' adalah sebuah kelompok atau tim yang menggunakan nama samaran. Hingga saat ini tidak ada siapapun yang mengetahui identitas asli dari orang atau kelompok samara tersebut. Nakamoto memperkenalkan bitcoin cryptocurrency yang menggunakan system elektronik peer-to-peer. Kemunculan Bitcoin didasari sebagai tanggapan terhadap lembaga keuangan yang sering melakukan privatisasi keuntungan dan kerugian yang disosialisasikan (Lerer \& McGarrigle, 2018). Dorongan lainnya dari kelahiran cryptocurrency didasari atas kebutuhan untuk membuat sistem yang memungkinkan bekerja dengan cepat dan murah, serta transaksi perantara pihak ketiga yang terpercaya seperti Bank (Bacao et al, 2018; Chapron, 2017 dan Sudzina, 2018). Selain itu juga banyaknya cendikiawan, penggemar dan futuris yang menganggap bahwasanya Bitcoin sebagai sebuah mata uang alternatf yang bernilai (Bouri et al, 2018).

Nakamoto (2008) dalam artikelnya yang berjudul "Bitcoin: A Peer-To-Peer Electronic Cash System" mengatakan bahwasanya bisnis yang menggunakan transaksi elektronik saat ini hampir semuanya bergantung kepada lembaga keuangan yang berfungsi sebagai pihak ketiga yang terpercaya untuk melakukan proses pembayaran elektronik. Dimana sistem tersebut sudah berjalan dengan sangat baik untuk sebagian besar transaksi, namun disisi lain masih menyisakan kelemahan. Diantaranya adalah transaksi yang sepenuhnya tidak dapat dikembalikan karena lembaga keuangan tidak dapat menghindari mediasi perselisihan. Biaya mediasi yang meningkat sehingga menjadi beban terhadap biaya transaksi dan keterbatasan dalam minimal ukuran transaksi serta biaya transaksi yang cukup besar. 
Dalam artikelnya Nakamoto (2008) juga mengatakan bahwasanya yang dibutuhkan saat ini adalah sistem pembayaran elektronik berdasarkan bukti kriptograpi dan bukan berdasarkan kepercayaan, sehingga memungkin dua belah pihak yang melakukan transaksi untuk melakukan transaksi secara langsung tanpa memerlukan orang yang dapat dipercaya melalui pihak ketiga. Dimana transaksi yang digunakan adalah transaksi yang berdasarkan sistem komputasi aman dan tidak dapat dirubah sehingga melindungi penjual dari penipuan dan mekanisme escrow rutin dapat dengan mudah diterapkan untuk melindungi pembeli. Sehingga ia mengusulkan sebuah solusi untuk mengatasi permasalahan pembayaran ganda dengan menggunakan distribusi peer-to-peer server timestamp untuk menghasilkan bukti komputasi berdasarkan urutan kronologis transaksi. Sistem yang digunakan akan aman selama Node atau alat penyimpanan bukti transaksi yang digunakan secara kolektif dengan menggunakan banyak daya CPU dibandingkan dikontrol oleh kelompok tertentu sehingga mampu terhindar dari peretas.

Nakamoto (2008) mendefiniskan koin elektronik sebagai sebuah tanda tangan digital yang berantai, dimana setiap pemilik koin melakukan transfer kepada pihak selanjutnya dengan menandatangani hash dari transaksi sebelumnya kepada kunci publik pemilik koin berikutnya secara digital. Penerima pembayaran dapat melakukan verifikasi tanda tangan untuk memverifikasi rantai kepemilikan sebagaimana tergambar pada skema berikut:

Gambar 1. Model Transaksi Menggunakan Blockchain

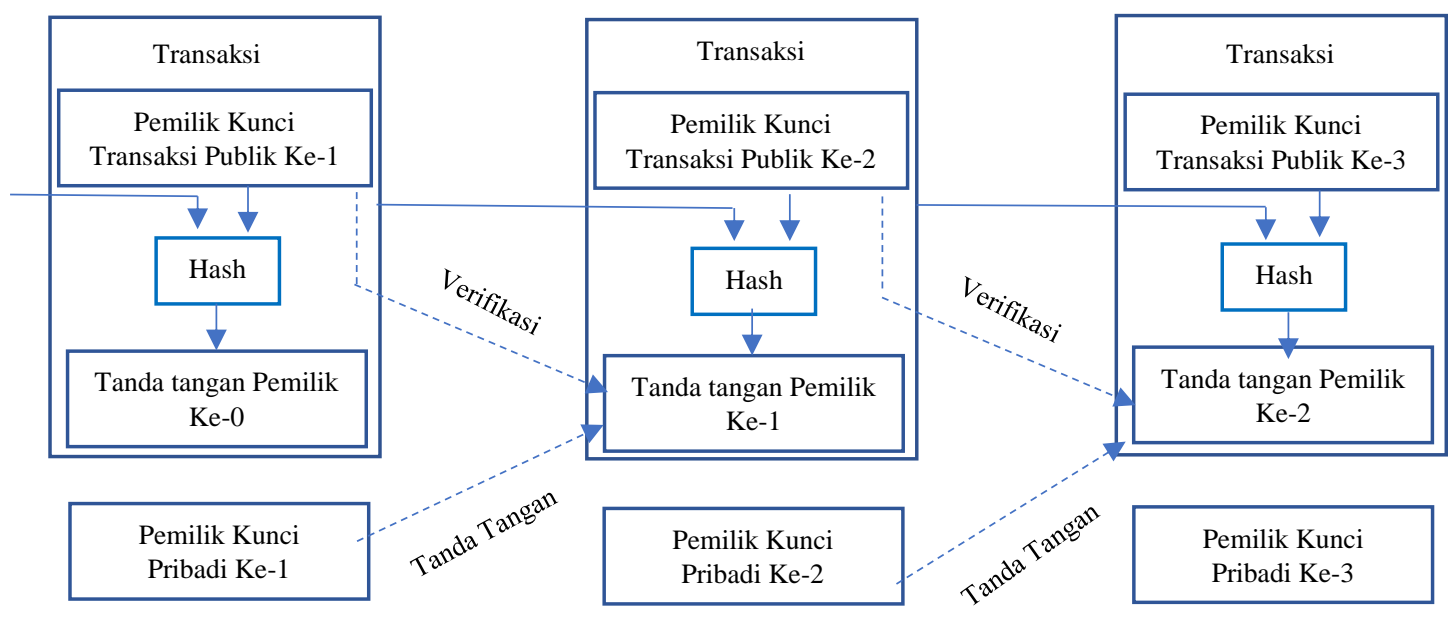

Sumber: Nakamoto (2008)

Salah satu kendala yang ada adalah penerima pembayaran tidak dapat memverifikasi bahwa si pemilik koin tidak melakukan pembelanjaan ganda, sehingga muncul sebuah solusi dimana diperkenalkan otoritas pusat yang terpercaya atau biasa dikenal dengan istilah Mint yang memeriksa setiap transaksi untuk menghindari pembelanjaan ganda. Setelah setiap koin berhasil dilakukan transaksi maka koin harus dikembalikan ke Mint untuk dapat mengeluarkan koin baru, dan hanya koin yang keluar dari Mint yang dipercaya dan tidak akan dibelanjakan secara ganda. Fungsi Mint 
Prosiding The 1st National Conference on Applied Business, Education, \& Technology (NCABET)"

Unversitas Bina Bangsa 2021

DOI Article : 10.46306/ncabet.v1i1.22

disini sama seperti halnya Bank. Dengan model digital menggunakan Mint maka semua transaksi dapat terverifikasi dan tercatat dan transparan diumumkan secara publik dengan tetap menjaga kerahasiaan si pemilik transaksi.

Pertanyaan selanjutnya yang muncul adalah bagaimana memastikan bahwasanya transaksi yang dilakukan selalu tercatat. Jawabannya mengacu kepada solusi yang ditawarkan dengan menggunakan timestamp server (server stempel waktu), dimana timestamp server bekerja dengan mengambil blok item yang akan diberi stempel waktu dan mempublikasikan hash secara luas, sama seperti halnya pada usenet post dimana pada transaksi dengan menggunakan cryptocurrency maka setiap stempel waktu membuktikan bahwa data adalah jelas, tepat, dan masuk ke dalam hash dimana setiap stempel waktu menyertakan stempel waktu sebelumnya di dalam hash sehingga membentuk rantai dengan stempel waktu berikutnya yang memperkuat yang sebelumnya.

Nakamoto (2008) menjelaskan bahwa timestamp yang diterapkan menggunakan system proof of work dengan menambahkan Nounce di dalam blok sampai nilai yang ditemukan yang memberikan hash blok bit nol yang diperlukan. Saat CPU telah berhasil untuk membuat blok tersebut maka disebut sebagai proof of work atau sebagai bukti kerja. Setelahnya maka CPU akan terus bekerja untuk merangkai blok-blok selanjutnya menjadi sebuah rantai blok. Untuk dapat mengimbangi peningkatan kecepatan perangkat keras dan minat dalam menjalankan Node dari waktu ke waktu, maka kesulitan dari proof of work akan ditentukan oleh pergerakan rata-rata yang ditargetkan dalam jumlah rata-rata blok per jam. Sehingga dapat disimpulkan bahwa jika blok yang dihasilkan terlalu cepat maka tingkat kesulitannya akan meningkat.

Langkah-langkah dalam menjalankan jaringan transaksi adalah sebagai berikut: (1) Transaksi baru di siarkan ke semua Node, (2) Setiap Node mengumpulkan semua transaksi baru ke dalam blok, (3) Setiap Node bekerja untuk menemukan proof of work yang sulit untuk blok nya, (4) Ketika sebuah Node menemukan sebuah proof of work maka ia akan menyiarkan blok tersebut ke semua Node, (5) Node menerima blok hanya jika semua transaksi didalamnya valid dan belum dibelanjakan, (6) Node menginformasikan penerimaan mereka terhadap blok dengan bekerja untuk membuat blok berikutnya didalam chain, menggunakan hash dari blok yang diterima sebagai hash sebelumnya. Node akan menganggap rantai terpanjang sebagai yang benar dan akan terus bekerja memperpanjangnya. Jika dua node menyiarkan versi yang berbeda dari blok berikutnya secara bersamaan maka beberapa Node akan dapat menerima satu atau yang lain terlebih dahulu.

Secara konvensi, transaksi pertama di blok adalah transakasi khusus yang memulai koin baru yang dimiliki oleh pembuat blok sebagai insentif atau kompensasinya. Sehingga dapat dikatakan Node berfungsi sama seperti halnya Bank dalam melakukan pencatatan dan verifikasi dari transaksi yang dilakukan antara pembeli dan penjual. Insentif juga dapat didanai dari biaya transaksi, apabila 
nilai keluaran dari satu transaksi kurang dari nilai inputnya, dimana selisihnya akan menjadi biaya transaksi yang ditambahkan menjadi nilai insentif. Dengan adanya insentif ini, maka akan membantu Node untuk tetap jujur.

Apabila dilihat dari tingkat keterbukaan informasi, maka cryptocurrency sama halnya juga dengan bank tradisional yang membatasi akses informasi ke pihak yang terlibat dan pihak ketiga yang terpercaya. Kewajiban untuk mengumumkan transaksi secara public menghalangi metode ini, tetapi privasi masih dapat dipertahankan dengan memutus aliran informasi di tempat lain dengan menjaga kunci public tetap anonym. Public tetap dapat melihat bahwa seseorang mengirim sejumlah uang kepada orang lain tetapi tanpa informasi yang menghubungkan transaksi tersebut kepada siapapun.

\section{Jenis-Jenis Cryptocurrency}

Nakamoto meluncurkan cryptocurrency pertama di dunia yang disebut dengan Bitcoin dengan jumlah koin yang beredar sebanyak 21.000.000 BTC dan Nakamoto tidak akan pernah menambah jumlah koin tersebut dengan berbagai alasan dimana salah satunya adalah untuk menjaga nilai Bitcoin itu sendiri sesuai dengan hukum Supply and Demand. Berselang tidak begitu lama tepatnya ditahun 2009 Bitcoin memiliki nilai tukar sebesar 1.309,03 BTC untuk 1 USD. Jika dilihat mundur kebelakang, kemunculan Bitcoin sebenarnya bukanlah yang pertama, karena pada tahun 1990an David Chaum seorang Matematikawan Amerika Serikat pernah meluncurkan mata uang digital yang disebut dengan DigiCash, namun sayangnya inovasi yang dikembangkan gagal berkembang. Berselang beberapa tahun semenjak kemunculan DigiCash, Wei Dai seorang engineer komputer lulusan Universitas Washington memperkenalkan B-Money yang dapat menjadi system kas elektronik terdistribusi tanpa nama, namun B-Money tidak pernah diluncurkan secara resmi. We Dai merupakan salah satu dari dua orang yang pernah di kontak oleh Satoshi Nakamoto pada tahun 2008, bahkan artikel tentang B-Money menjadi rujukan Nakamoto pada artikelnya.

Transaksi pertama yang dilakukan dengan menggunakan Bitcoin terjadi pada tanggal 18 Mei 2010 dimana Hanyes seorang warga negara Amerika Serikat membeli dua Loyang Pizza dengan menggunakan 10.000 BTC dimana harga dua Loyang Pizza pada saat itu sebesar 25 USD, yang artinya 1 BTC sama dengan 0,0025 USD. Pada tahun 2013 lahir dua cryptocurrency baru yang merupakan turunan atau alternatif dari Bitcoin yang disebut dengan Altcoin, dimana Altcoin pertama diberi nama DogeCoin dengan jumlah koin yang tersedia sebanyak 100.000.000.000 DOGE. Tidak berselang lama setelah kemunculan DogeCoin, muncul kompetitor baru yang diberi nama dengan Catcoin dengan symbol CAT dan jumlah koin yang tersedia sebanyak 21.000.000 CAT.

Jenis cryptocurrency yang beredar di dunia dari tahun ke tahun terus mengalami peningkatan, dari 66 jenis pada tahun 2013, kemudian meningkat menjadi 562 jenis pada tahun 2015 dan pada 
Prosiding The 1st National Conference on Applied Business, Education, \& Technology (NCABET)"

Unversitas Bina Bangsa 2021

DOI Article : 10.46306/ncabet.v1i1.22

tahun 2017 meningkat lagi menjadi 1.335 jenis, kemudian meningkat menjadi 2.817 jenis pada tahun 2019 dan pada tahun 2021 tepatnya dibulan februari jenisnya meningkat menjadi 4.501 jenis sebagaimana terlihat pada gambar 1.

Gambar 1. Perkembangan Jenis Cryptocurrency Dari Tahun Ke Tahun

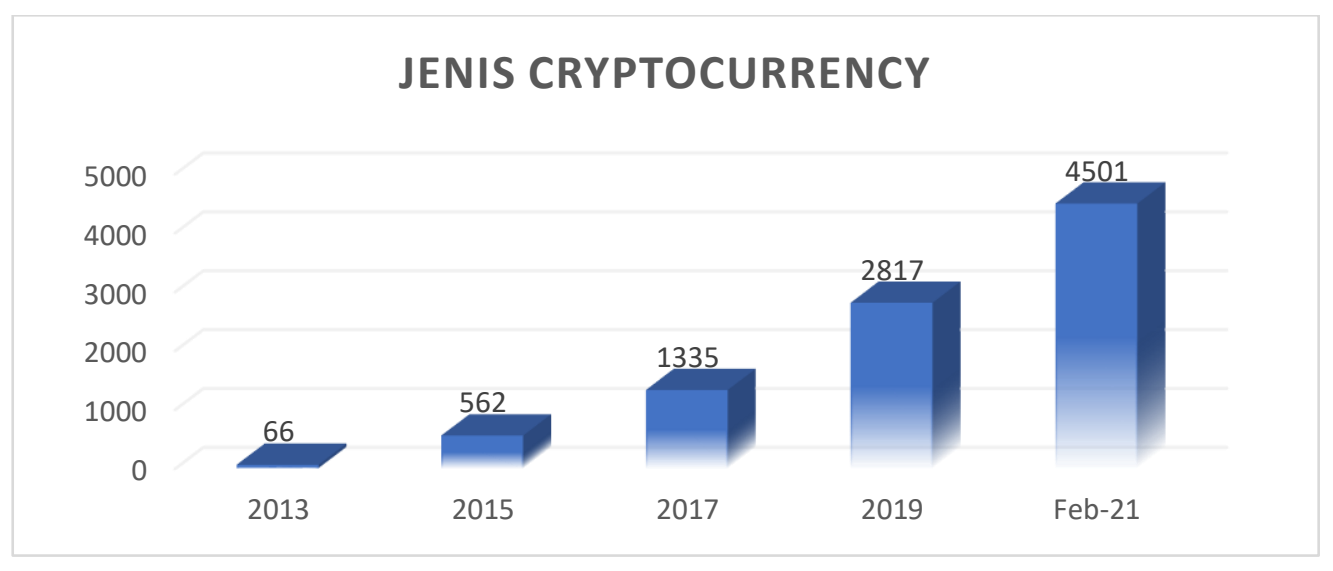

Sumber:

Databoks (2021)

Meskipun banyak jenis cryptocurrency yang beredar, namun tidaklah semua cryptocurrency diizinkan untuk diperdagangkan di Indonesia mengingat Badan Pengawas Perdagangan Berjangka Komoditi (Bappebti) hanya mengizinkan sebanyak 229 jenis cryptocurrency dikarenakan bukan hanya memiliki potensi keuntungan yang besar akan tetapi juga memiliki tingkat risiko yang sangat tinggi. Hingga saat ini Bitcoin masih menjadi cryptocurrency terpopuler dengan nilai tukar yang paling tinggi terhadap USD. Berikut adalah 30 jenis cryptocurrency teratas berdasarkan besarnya nilai kapitalisasi pada tanggal 24 September 2021:

Tabel 1. Cryptocurrency Dengan Jumlah Kapitalisasi 30 Teratas

\begin{tabular}{|c|c|c|c|c|c|c|c|}
\hline No & Logo & $\begin{array}{l}\text { Nama } \\
\text { Crypto }\end{array}$ & $\begin{array}{c}\text { Jumlah Koin } \\
\text { Tersedia }\end{array}$ & No & Logo & $\begin{array}{l}\text { Nama } \\
\text { Crypto }\end{array}$ & $\begin{array}{c}\text { Jumlah Koin } \\
\text { Tersedia } \\
\end{array}$ \\
\hline 1 & & Bitcoin & 21 Juta & 16 & & Litecoin & 84 Juta \\
\hline 2 & & Ethereum & 117,613 Juta & 17 & & Bitcoin Cash & 21 Juta \\
\hline 3 & & HEX & $633,543 \mathrm{M}$ & 18 & & Algorand & $10 \mathrm{M}$ \\
\hline 4 & & Tether & $71,366 \mathrm{M}$ & 19 & & $\begin{array}{l}\text { Wrapped } \\
\text { Bitcoin }\end{array}$ & 206,421 Ribu \\
\hline 5 & & Cardano & $45 \mathrm{M}$ & 20 & & Filecoin & 108,701 Juta \\
\hline 6 & & $\begin{array}{l}\text { Binance } \\
\text { Coin }\end{array}$ & 168,137 Juta & 21 & & $\begin{array}{l}\text { Internet } \\
\text { Computer }\end{array}$ & 469,214 Juta \\
\hline 7 & & XRP & $100 \mathrm{M}$ & 22 & & Polygon & $10 \mathrm{M}$ \\
\hline 8 & & Solana & 504,506 Juta & 23 & & Cosmos & 279,499 Juta \\
\hline 9 & & USD Coin & $29.42 \mathrm{M}$ & 24 & & Stellar & $50,002 \mathrm{M}$ \\
\hline
\end{tabular}




\begin{tabular}{|c|c|c|c|c|c|c|c|}
\hline 10 & $P$ & Polkadot & $1,103 \mathrm{M}$ & 25 & 8 & FTX Token & 352,17 Juta \\
\hline 11 & D & Dogecoin & $131,371 \mathrm{M}$ & 26 & & Tron & $100,851 \mathrm{M}$ \\
\hline 12 & (N) & Avalanche & 720 Juta & 27 & & Dai & $6,579 \mathrm{M}$ \\
\hline 13 & 6 & Uniswap & $1 \mathrm{M}$ & 28 & & $\begin{array}{l}\text { Ethereum } \\
\text { Classic }\end{array}$ & 210,7 Juta \\
\hline 14 & 4 & Terra & 994,813 Juta & 29 & & VeChain & $86,713 \mathrm{M}$ \\
\hline 15 & 0 & ChainLink & $1 \mathrm{M}$ & 30 & & Theta Token & $1 \mathrm{M}$ \\
\hline
\end{tabular}

Sumber: id.tradingview.com (September, 2021)

\section{Fluktuasi Nilai Cryptocurrency}

Cryptocurrency memiliki fluktuasi nilai yang sangat cepat berubah, sebagai contoh adalah Bitcoin yang menjadi cryptocurrency pertama yang dipublish, dalam sembilan tahun terakhir nilainya terhadap USD tidak selalu naik, bahkan pernah sempat anjlok sangat dalam. Fluktuasi nilai cryptocurrency disebabkan oleh beberapa faktor, antara lain diakibatkan oleh penawaran dan permintaan. Semakin banyak permintaan maka nilai barang mengalami kenaikan dan semakin banyak penawaran maka akan terjadi penurunan harga pada nilai cryptocurrency tersebut. Bitcon diawalnya tidak memiliki nilai jual atau nilai tukar, namun lambat laun telah mengalami peningkatan nilai harga jual. Dimana nilai jual yang pertama kali sebesar 1.309,03 BTC $=1$ USD, artinya adalah pada awal peluncuran Bitcoin, nilainya 1 BTC hanya sekitar 0,00076 USD, dan pihak yang pertama kali melakukan layan jual beli Bitcoin adalah New Liberty Standard pada 5 oktober 2009.

Penyebab fluktuasi lainnya adalah persepsi masyarakat. Apabila Bitcoin mendapatkan persepsi baik maka permintaan terhadap Bitcoin akan meningkat sehingga akan meningkatkan nilai tukar atau nilai jual Bitcoin, sebaliknya apabila Bitcoin mengalami persepsi yang kurang baik, maka harga Bitcoin akan menurun (Azizah \& Irfan, 2020), hal ini dapat dilihat pada gambar 1. Faktor lainnya yang mempengaruhi nilai Bitcoin adalah fungsinya sebagai alat pembayaran. Beberapa negara sudah menggunakan Bitcoin sebagai alat pembayaran seperti untuk membayar transaksi di Restoran, Apartemen, dan lain-lain. Hal tersebut menyebabkan BTC sebagai alat pembayaran sehingga nilainya menjadi meningkat.

Pada periode bulan Januari sampai dengan Mei 2018, nilai BTC yang ditransaksikan telah mencapai US\$ 100 miliar. Faktor lainnya adalah kebijakan pemerintah, terlebih jika berasal dari negara besar dan berpengaruh seperti Amerika dan China. Pada saat China menyatakan Bitcoin illegal, maka secara langsung BTC kehilangan nilainya terutama untuk transaksi yang berkaitan dengan China. Faktor selanjutnya adalah isu buruk, Bitcoin rentan terhadap isu buruk sama seperti halnya nilai saham.

Gambar 1. Fluktuasi Nilai Tukar Bitcoin Dari Waktu ke Waktu 


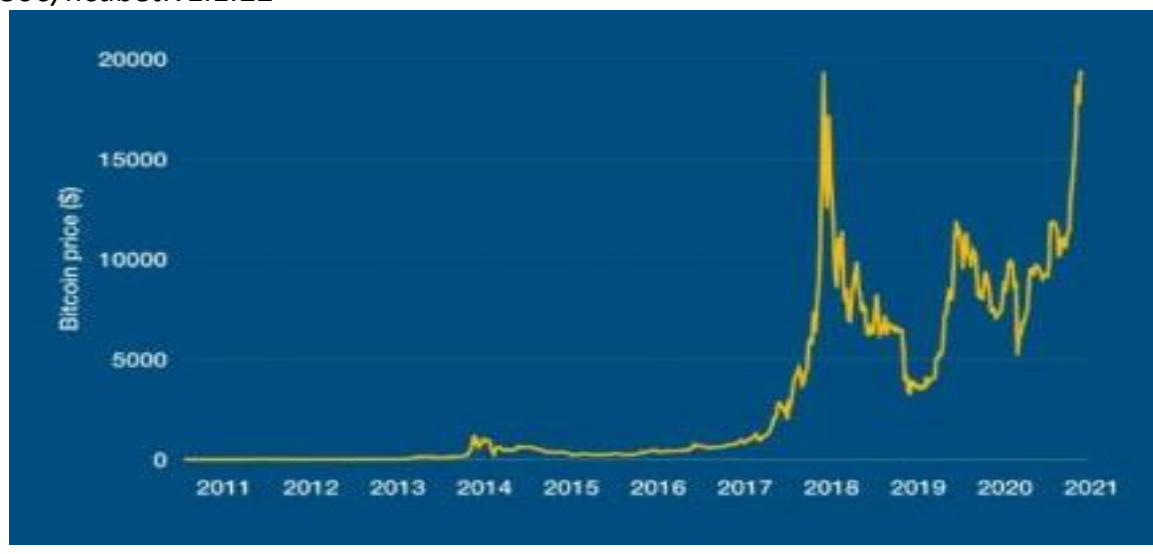

Sumber: The History of Bitcoin Price (Lifepal, Juli 2021)

Berdasarkan rangkuman peneliti dari berbagai sumber, nilai tukar BTC pada periode penutupan akhir tahun dari sejak pertama kali diluncurkan hingga September 2021 telah mengalami berbagai macam fluktuasi dan juga lompatan yang sangat signifikan, sebagaimana terangkum pada pada tabel berikut 2:

Tabel 2. Nilai Tukar BTC Terhadap USD Dari Tahun Ke Tahun

\begin{tabular}{|c|r|r|r|r|}
\hline $\begin{array}{c}\text { Penutupan } \\
\text { Akhir Tahun }\end{array}$ & BTC & US\$ & $\begin{array}{c}\text { Perubahan Dibanding } \\
\text { Tahun Sebelumnya } \\
\text { (US } \$)\end{array}$ & $\begin{array}{c}\text { Persen Perubahan Dibanding } \\
\text { Tahun Sebelumnya } \\
(\%)\end{array}$ \\
\hline Oktober 2008 & 1 BTC & Dirilis & & $40.689,47 \%$ \\
\hline 2009 & 1 BTC & 0,00076 USD & & $1.893,55 \%$ \\
\hline 2010 & 1 BTC & 0,0025 USD & 0,31 USD & $117,48 \%$ \\
\hline 2011 & 1 BTC & 6,18 USD & 5,87 USD & $5.487,80 \%$ \\
\hline 2012 & 1 BTC & 13,44 USD & 7,26 USD & $-50,29 \%$ \\
\hline 2013 & 1 BTC & 751,00 USD & 737,56 USD & $16,70 \%$ \\
\hline 2014 & 1 BTC & 373,34 USD & $-377,66$ USD & $1.964,67 \%$ \\
\hline 2015 & 1 BTC & 435,70 USD & 62,36 USD & $-80,97 \%$ \\
\hline 2016 & 1 BTC & 952,50 USD & 516,80 USD & $92,22 \%$ \\
\hline 2017 & 1 BTC & 19.666 USD & $18.713,50$ USD & $303,17 \%$ \\
\hline 2018 & 1 BTC & 3.742 USD & $-15.924,00$ USD & $46,67 \%$ \\
\hline 2019 & 1 BTC & 7.193 USD & $3.451,00$ USD & \\
\hline 2020 & 1 BTC & 29.000 USD & $21.807,00$ USD & \\
\hline September 2021 & 1 BTC & 42.533 USD & $13.533,00$ USD & \\
\hline
\end{tabular}

Sumber: Hasil data sekunder (2021)

\section{Pro dan Kontra Penggunaan Cryptocurrency}

Banyak yang menggunakan cryptocurrency sebagai pengganti uang tunai maupun uang non tunai ketika diperlukan. Penggunaannya yang mudah, modern dan cepat menjadi alasan untuk digunakan. Pemanfaatan dan penggunaan cryptocurrency dilakukan dengan tiga acara antara lain; pembayaran, investasi jangka panjang dan perdagangan dengan cryptocurrency atau yang dikenal dengan cryptocurrency trading (Azizah \& Irfan, 2020). Secara umum peneliti menjabarkan penggunaan cryptocurrency sebagai berikut:

a. Cryptocurrency sebagai alat pembayaran 
Peningkatan Bitcoin sebagai alat pembayaran semakin meningkat dari tahun ke tahun, hal ini disebabkan kemudahan dalam penggunaannya terlebih saat pandemik Covid-19 berlangsung pada tahun 2020, mayoritas masyarakat menghindari kontak langsung salah satunya menghindari pembayaran dengan menggunakan uang tunai. Sehingga penggunaan cryptocurrency semakin banyak diminati, bahkan sudah ratusan perusahaan yang menggunakan cryptocurrency sebagai alat pembayaran.

Diantara perusahan-perusahaan yang menggunakan Cryptocurrency sebagai alat pembayaran banyak diantaranya adalah perusahaan besar, seperti Microsoft, Paypal, Overstock, Whole Food Market, Etsy, Starbucks, Newegg, Home Depot, Rakuten Twitch, Pavilion Hotels \& Resorts, Asuransi AXA, Tesla, Visa, airBaltic, LOT Polish Airlines, Rumah Lelang Sotheby’s, Coca Cola, Expedia, Lush dan Amazon, Apple, Namecheap, Shopify, Dish Network, ExpressVPN, PureVPN, OKCupid, Wordpress.Reddit, Bloomberg, Treehouse, Playstation Network, Green Main Gaming, Zynga. Expedia, Webjet, CheapAir, Virgin Galatic.

b. Cryptocurrency sebagai investasi

Sebagaimana telah dibahas pada bagian sebelumnya dimana Cryptocurrency memiliki fluktuasi nilai yang sangat cepat berubah bukan hanya hitungan hari namun dalam hitungan jam bahkan menit. Hal ini tentunya menimbulkan potensi risiko, namun jika dilihat pergerakannya dari tahun ke tahun seperti halnya Bitcoin, maka tidak salah jika cryptocurrency dapat dijadikan sebagai asset tidak bergerak yang dapat digunakan dengan tujuan sebagai alat investasi. Sebagaimana diketahui bersama bahwasanya Nakamoto (2008) mengeluakan jumlah BTC dengan jumlah yang terbatas yaitu sebanyak 21 Juta koin, dimana jumlah tersebut tentunya tidak akan bertambah namun disisi lain semakin banyak masyarakat yang meminati koin tersebut yang sehingga tentunya kecendrungan akan kenaikan nilai dari BTC akan semakin meningkat dari waktu ke waktu.

Karakteristik cryptocurrency yang diciptakan oleh Nakamoto sangat mirip dengan emas, dimana emas memiliki junlah yang terbatas, maka Bitcoin pun sama memiliki jumlah yang terbatas. Emas diperoleh dengan cara ditambang, maka Bitcoin pun memiliki karakteristik yang sama dimana untuk mendapatkannya para miner (Penambang) perlu bekerja dengan menambang untuk mendapatkan proof of work dan pada endingnya mendapatkan kompensasi berupa koin dari hasil penambangan tersebut.

Karakteristik lainnya adalah emas akan cenderung memiliki nilai aman dan bahkan meningkat pada saat terjadi inflasi karena jumlahnya yang sangat langka, maka karakteristik tersebut juga sama dimiliki oleh Cryptocurrency hal ini terbukti dimana untuk mendapatkannya para miner membutuhkan usaha yang tidak mudah dan biaya yang tidak murah, terutama biaya operasional listrik selama menjalankan server dan aplikasi komputer yang digunakan untuk menambang. Dengan 
Prosiding The 1st National Conference on Applied Business, Education, \& Technology (NCABET)"

Unversitas Bina Bangsa 2021

DOI Article : 10.46306/ncabet.v1i1.22

jumlah yang semakin terbatas karena ditambang oleh seluruh miner di dunia maka tingkat kesulitannya pun akan semakin meningkat, sehingga harganya akan meningkat. Namun tentunya peningkatan nilai Cryptocurrency akan lebih cenderung kepada volumenya dan psikologis market crypto.

Selama masa krisis ekonomi internasional, pemerintahan mencetak uang konvensional dengan jumlah yang lebih banyak dari biasanya sehingga berujung pada inflasi. Hal ini menyebabkan para investor memiliki kecendrungan untuk menginvestasikan assetnya kepada investasi jangka panjang yang stabil, jika dulu diinvestasikan kepada emas dan perak maka banyak yang melakukan investasinya kepada Bitcoin, dan bahkan banyak diantara para investor yang menganggapnya sebagai asset Save Haven atau asse yang dapat melindungi diri dari inflasi.

c. Cryptocurrency sebagai komoditi perdagangan

Cryptocurrency saat ini sudah menjadi komoditi masyarakat luas untuk diperdagangkan, bahkan semakin banyak dijumpai komunitas trader dari cryptocurrency yang bermunculan untuk melakukan jual beli crypto baik sebagai investasi maupun untuk komoditi perdagangan untuk mengambil keuntungan dari fluktuasi harga crypto tersebut. Bahkan di Indonesia sendiri sudah terdapat ICO atau Initial Coint Offering yaitu suatu sarana untuk mengumpulkan dana melalui penawaran suatu jenis koin baru atau layanan cryptocurrency baru sehingga investor yang tertarik akan memberikan penawaran baik menggunakan cryptocurrency seperti Bitcoin ataupun menggunakan uang real, kemudian pihak investor akan menerima token Cryptocurrency.

Seperti halnya mata uang real, cryptocurrency seperti Bitcoin juga memiliki satuan dari pecahan terbesar hingga terkecil. Pada Bitcoin misalnya 1 BTC dapat dipecah menjadi mBTC (miliBitcoin) dimana $1 \mathrm{BTC}=1.000 \mathrm{mBTC}$. Ada juga pecahan $\mu \mathrm{BTC}$ (mikro-Bitcoin) dimana $1 \mathrm{BTC}=$ 1.000.000 $\mu \mathrm{BTC}$. Hingga kepada satuan yang terkecil yaitu satoshi sesuai dengan penemunya, dimana 1 BTC $=100.000 .000$ satoshi. Dengan adanya satuan ini maka masyarakat akan dapat dengan mudah membeli Bitcoin sesuai dengan jumlah kesanggupan yang dimilikinya.

Perusahaan cryptocurrency biasanya akan menggunakan dana dari investor tadi sebagai sarana dalam mencapai tujuannya yaitu meluncurkan produk baru atau memulai crypto. Keuntungan yang akan didapatkan oleh investor adalah pada saat koin baru tersebut mengalami peningkatan nilai terhadap mata uang real apabila masa ICO telah selesai maka koin baru akan dirilis ke masyarakat umum dan masyarakat melakukan transaksi atau berinvestasi, biasanya harga akan terus mengalami kenaikan sehingga investor ICO akan mendapatkan keuntungan yang banyak. Namun bisa juga sebaliknya, dimana setelah ICO yang terjadi adalah koin baru tidak diminati oleh masyarakat sehingga yang muncul adalah kerugian. 
Cryptocurrency bukan hanya memiliki potensi jangkan panjang dan manfaat yang banyak sekali digunakan sebagai alat transaksi, dengan menggunakan kemajuan teknologi distributed ledger atau buku besar yang terdistribusi yang dikenal dengan blockchain telah menghadirkan mekanisme validasi yang aman, dan kolaborasi masal yang tidak terdesentralisasi sehingga tidak bergantung kepada perantara keuangan terpusat. Namun disisi lain juga memiliki risiko, tantangan, dan adanya kepastian hukum yang masih belum pasti. Dengan sistem keuangan DeFi (Decentralized Finance) yang menghilangkan ketergantungan terhadap otoritas keuangan pusat dan menggantukannya dengan para validator yang tersebar di seluruh penjuru dunia menjadikan transaksi lebih cepat, mudah dan murah namun tetap mempertahankan anonimitas dan kepercayaan telah menjadi ancaman bagi sistem perbankan konvensional saat ini hingga kepada fintech, hal inilah yang memunculkan sistem DeFi sebagai sebuah cara disrupsi pada sektor keuangan. Sistem ini mampu menjadi alternatif sistem keuangan global yang terbuka untuk setiap layanan keuangan dan sudah biasa kita gunakan seharihari. Layanan keuangan seperti tabungan, keuangan, pinjaman, trading, asuransi, dan transaksi lainnya dapat dengan mudah dilakukan oleh siapapun, dimanapun, dan kapanpun dengan menggunakan media smartphone dan koneksi internet.

Dengan adanya Initial Coint offering (ICO) telah banyak digunakan oleh banyak perusahaan untuk mendapatkan modal yang tidak diatur kedalam industri transaksional, hal ini telah meningkatkan minat dari para investor dan juga para sekuritas nasional dan badan pengatur keuangan (Cumming te al, 2019). Dengan sistem yang terdesentralisasi saat ini tentunya menjadi perhatian tersendiri bagi masyarakat dan dapat menjadi nilai positif dengan peningkatan minat kewirausahaan dalam melakukan investasi maupun transaksi perdagangan yang dapat mendorong ekonomi kemasyarakatan (Ahlstrom, 2010). Namun disisi lain hal tersebut harus dijadikan perhatian ekstra bagi regulator dalam hal pengawasan modal investasi dan sistem perpajakan yang harus mulai berinovasi terhadap asset crypto (Spulber, 2008).

Beberapa hal yang membuat dan menyebabkan adanya kontra terhadap mata uang crypto disebabkan telah terjadinya beberapa kasus beberapa tahun yang lalu, diantaranya adalah:

1. Pada tahun 2016 sebuah entitas yang bernama Decentralized Autonomous organization (DAO) yaitu sebuah organisasi otonom yang terdesentralisasi menjadi salah satu entitas yang paling banyak didanai dan sukses dalam sejarah melalui ICO dalam waktu kurang dari tiga puluh hari telah mampu mengumpulkan lebih dari US\$150 Ether senilali jutaan cryptocurrency. DAO tersebut didanai melalui Ether oleh investor ekuitas yang berdiri secara global, tidak terdaftar sebagai badan hukum dinegara berdaulat manapun yang dan tidak memiliki karyawan sehingga tidak memiliki struktur manajemen seperti direktur, direktur eksekutif dan tim manajemen (Dale, 2016). Namun sayangnya sebelum usaha tersebut dapat dijalankan, terlebih dahulu terjadi 
serangan cyber yang telah menghabiskan modal DAO sebanyak sepertiganya (Popper, 2016). hal ini telah melanggar undang-undang sekuritas Amerika, sehingga diperlukannya sebuah struktur badan hukum yang jelas untuk mencapai tujuan dari ICO yaitu meningkatkan modal guna meluncurkan protokol blockchain yang sukses serta menguntungkan bagi para investornya.

2. Kasus penipuan yang terjadi terkait dengan investasi virtual yang menggunakan nama GainBitCoin di india. Dimana pemilik perusahaan tersebut adalah Amit Bhardwaj telah menjanjikan kepada para investor untuk pengembalian dana investasinya sebanyak 10\% dari investasi crypto token mereka. Namun yang terjadi justru perusahaan menggunakan skema pemasaran multi-level marketing yang bertujuan untuk mengekstrak Bitcoin cair dari investor dan menyediakan kembali kedalam bentuk cryptocurrency lainnya yang disebut dengan MCAP. Kasus penipuan ini menggunakan skema Ponzi yang telah merugikan investor sebesar US\$300 juta (Anupam, 2018).

3. Selain dua kasus di atas, banyak juga ICO yang telah dilaunching pada tahun 2017 dimana telah terkumpul dana sebanyak US\$ 5,6 miliar secara kolektif dari para investor, namun hanya 48\% yang berhasil (William, 2018). Untuk itulah penting bagi regulator untuk menetapkan adanya skema dan regulasi yang jelas serta mengikat untuk dapat mengamankan asset para investor dan juga memastikan bahwasanya perusahaan yang melakukan start up memiliki kompetensi yang sesuai.

4. Adanya skema pencucian uang dari hasil kegiatan bisnis illegal e-currency Liberty Reserve yang akhirnya ditutup di Costa Rica. Bahkan sebelumnya si pemilik e-currency Liberty Reserve dan rekannya merupakan pemilik GoldAge Inc yang pada tahun 27 Juli 2006 telah ditetapkan bersalah oleh Departemen Kehakiman Amerika akibat transaksi illegal sebesar US\$ 30 Juta dalam bentuk uang digital keseluruh dunia sejak 2002 kepada kliennya diberbagai daerah dengan cara yang mudah tanpa menggunakan dokumen resmi yang ketat. Dimana untuk membuka account Liberty Reserve seseorang hanya perlu mengisi nama, alamat, alamat email, dan tanggal lahir. Hal tersebut telah mengundang banyak organisasi kriminal untuk membuka rekening di Liberty Reserve. Sehingga kemungkinan uang yang telah ditransaksikan antara periode tersebut berasal dari kegiatan bisnis illegal seperti narkoba, pornografi, dan pemangkir pajak. Akibat dari penutupan Liberty Reserve, banyak nasabahnya yang kehilangan uangnya dan hingga kini belum jelas nasibnya.

5. Adanya kasus peretasan dari Hacker terhadap tempat penukaran Bitcoin. Kasus yang paling terkenal terjadi pada tahun 2014 di Jepang yang menimpa Mt Gox, dimana sekitar 25.000 investor kehilangan sekitar 650.000 Bitcoin atau sekitar US\$ 400 Juta dan jika dikonversi ke Rupiah mencapai Rp. 6 triliun. Hal ini menyebabkan kerugian yang sangat besar bagi investor, karena 
investor tidak dilindungi dengan asuransi (Bauer \& Ahmad, 2017). Peretasan yang terjadi pada Mt Gox telah memaksa Karpeles sebagai pemiliknya untuk menyatakan bahwa perusahaan telah bangkrut dan harus ditutup. Dalam konverensi pers, Karpeles mengatakan bahwasanya Mt Gox memiliki kelamahan sistem. Pasca kejadian tersebut dengan cepat menyebabkan harga Bitcoin sempat jatuh terpuruk.

6. Peretasan identitas melalui media sosial yang kemudian digunakan oleh para peretas untuk mencari informasi seperti alamat email, nomor ponsel, data individu pribadi seperti nama panggilan masa kecil, nama hewan kesayangan, yang biasanya merupakan sandi umum yang digunakan oleh pengguna online. Setelah mendapatkan data tersebut biasanya peretas akan mencoba meretas cryptocurrency ke dalam dompet virtual si pemilik dan kemudian dikonversi ke mata uang nyata atau cryptocurrency lainnya (Bauer \& Ahmad, 2017).

7. Adanya peretas yang menggunakan cryptocurrency sebagai jaminan untuk menebus sistem komputer perusahaan atau sistem komputer sebuah kota, dimana data hanya akan diberikan apabila telah ditransfer sejumlah uang dengan menggunakan tebusan berupa cryptocurrency. Hal ini mendapat sorotan banyak pihak, salah satunya adalah terjadi pada tahun 2017 saat serangan siber dengan skala besar yang telah menginfeksi lebih dari 75.000 komputer di 99 negara dan menuntut tebusan dalam bentuk cryptocurrency. Serangan tersebut telah mengenai beberapa perusahaan besar di Spanyol dan lebih dari 1.000 komputer di Kementrian Urusan Dalam Negeri Rusia, Kementrian Darurat Rusia, dan perusahaan telekomunikasi Rusia MeganFox. Serangan tersebut juga berdampak kepada banyak rumah sakit Dinas Kesehatan di Inggris dan Skotlandia bahkan di Indonesia perangkat pemeras ini telah menyerang sejumlah komputer di berbagai rumah sakit umum dengan meminta tebusan sejumlah uang untuk mengembalikan komputer ke sediakala. Umumnya peretas akan menuntut pembayaran sekitar US\$ 300 dalam Bitcoin dalam jangka waktu 3 hari atau sebesar US\$ 600 dalam waktu 7 hari.

8. Kasus pembajakan crypto, dimana peretas mengidentifikasi metode yang digunakan untuk menambang cryptocurrency. Peretas akan menggunakan malware untuk membajak perangkat seluler atau komputer yang digunakan oleh para miner tanpa disadari oleh para miner maupun situs web. Dampaknya adalah para miner yang terbagi profitnya dari hasil penambangan yang dilakukan tanpa disadari.

9. Penipuan pajak, dimana biasanya para pembayar pajak akan menyembunyikan pendapatan dan assetnya dari otoritas pajak negara asal, dan yang paling diminati oleh para pembayar pajak adalah fasilitas lingkungan yang lebih sedikit pajak dan tidak tunduk kepada pertukaran informasi karena peraturan kerahasiaan Bank yang sangat ketat (Westhuizen, 2017). Cryptocurrency memegang teguh konsensus atas kerahasiaan para pemilik koinnya sehingga untuk sementara ini belum 
memiliki yurisdiksi antara lain terhadap yuridiksi operasi dan juga anonimitas yang memungkinkan mereka tidak menjadi sumber pendapatan pajak (Marian, 2013). Oleh karenanya saat ini banyak negara yang telah membuat regulasi terkait dengan cryptocurrency sebagai sebuah asset properti. Sehingga prinsip perpajakan yang umumnya berlaku untuk transaksi properti berlaku juga untuk transaksi cryptocurrency. Seorang wajib pajak menerima mata uang virtual sebagai pendapatannya maka harus dinyatakan sebagai pendpatan yang dihitung dengan wajar pada tanggal pembayaran atau tanda terima. Setiap keuntungan atau kerugian dalam pertukaran cryptocurrency dianggap sebagai keuntungan modal atas asset tersebut, yang pada akhirnya akan meminimalkan penggelapan pajak (Internal Revenue Service, 2018).

\section{Regulasi Cryptocurrency di Berbagai Negara}

a. Jepang

Jepang merupakan negara yang telah mengesahkan aturan terkait dengan cryptocurrency. Jepang telah menyetujui Bitcoin sebagai alat tukar untuk transaksi digital. Bahkan regulator yang mengatur tentang peredaran mata uang Yen telah menyetujui undang-undang terkait dengan Bitcoin yang dapat membantu memperluas jangkauan teknologi informasi pada sektor perbankan. Dengan regulasi ini maka di Jepang marak retailer yang menerima pembayaran dengan Bitcoin seperti restoran, hotel, travel agent, money exchange, dan berbagai sektor lainnya. Akan tetapi mata uang Yen tetap menjadi alat utama pembayaran dan mata uang Jepang.

b. Amerika Serikat

Seperti diberbagai negara lainnya, di Amerika sendiri cryptocurrency awalnya dianggap sebagai alat tukar yang tidak sah untuk digunakan dalam transaksi perdagangan. Namun lambat laun regulasi mulai berubah, pada tahun 2013 Internal Revenue Service (IRS) menganggap bahwasanya cryptocurrency awalnya hanya sebagai komoditi asset sama seperti halnya tanah. Negara bagian di Amerika sendiri terbagi menjadi tiga jenis, yang pertama adalah negara bagian yang telah memiliki regulasi resmi terkait penggunaan cryptocurrency, yang kedua adalah negara bagian yang sedang mempertimbangkan untuk mengesahkan undang-undang terkait cryptocurrency dan yang ketiga adalah negara bagian yang belum sama sekali regulasi terkait cryptocurrency.

Wyaoming menjadi salah satu negara bagian yang paling fokus dan ramah terhadap penggunaan cryptocurrency. Bahkan telah menyetujui Decentralized Autonomy Organization (DAO) pertama yang diakui secara hukum di Amerika. Kantor Sekertaris Negara Wyoming mengakui The American CryptoFed DAO sebagai badan hukum pada bulan Juli 2021 sama seperti halnya Perseroan Terbatas. Bahkan The American CryptoFed DAO yang didirikan oleh mobile 
banking mSHIFT mempromosikan dua token yang kebal dari pengaruh inflasi dan deflasi serta memfasilitasi transaksi dengan kecepatan tinggi dan bebas biaya.

c. Uni Eropa

Uni Eropa secara resmi mengakui penggunaan cryptocurrency sebagai alat tukar dan alat pembayaran pada transaksi digital sebagai alat pembayaran. Namun Uni Eropa mulai mempertegas aturan terkait cryptocurrency dengan membuat proposal perubahan terhadap aturan transfer cryptocurrency, dimana perusahaan terkait wajib untuk mengumpulkan data detail pengirim dan ppenerima cryptocurrency guna melacak transfer yang menggunakan cryptocurrency sehingga membantu pencegahan pencucian uang dan pendanaan terorisme.

Komisi Eropa mengatakan bahwa transfer crypto akan tunduk kepada aturan Anti Money Laundring (AML). Dengan aturan baru ini maka akan memaksa perusahaan yang ebrgerak pada jasa crypto untuk melakukan pencatatan nama, alamat, nomor rekening, tanggal lahir dan penerima mereka serta tidak lagi tidak lagi menggunakan dompet crypto anonym sama seperti halnya rekening bank anonym yang sudah dilarang di Eropa. Setidak nya proposal ini membutuhkan waktu selama dua tahun kedepan untuk dapat disahkan menjadi undang-undang, mengingat harus terlebih dahulu mendapatkan persetujuan dari negara-negara anggota parleman Eropa.

d. United Kingdom

Dengan keluarnya Inggris dari Uni Eropa akibat tekanan politik dan ketidakpastian ekonomi menjadi ancaman tersendiri bagi negara tersebut, mengingat saat ini banyak platform yang termotivasi unutk pindah ke Amsterdam, Paris dan Frankfurt. Hal ini membuat otoritas keuangan inggris untuk mengumumkan bahwa mereka akan bekerja sama dengan komite perbendaharaan inggris untuk menganalisa risiko dan peluang yang terkait dengan cryptocurrency dan teknologi blockchain (Tomzak, 2018). Pemerintah Inggris telah meminta kepada perusahan crypto untuk mendaftarkan perusahaannya secara legal di Inggris di bawah aturan Financial Conduct Authority (FCA) sejak awal tahun 2021. Untuk memerangi pencucian uang dan mencegah pendanaan terorisme, dan disisi lain juga untuk dapat melindung investor sebagai konsumen.

Dengan adanya penerapan Financial Action Task Force (FATF) untuk asset crypto maka diharapkan perusahaan yang bergerak dibidang jasa transfer cryptocurrency untuk memastikan bahwa informasi pribadi pembuat dan penerima transfer cryptocurrency ditransmisikan dan dan diterima bersamaan dengan transfer dengan menggunakan format yang sesuai dan diusulkan bahwa apabila penerima transfer harus dapat dicegah untuk menarik dana diatas 1.000 Poundsterling jika informasi yang diperlukan tidak ada.

e. Kanada 
Kanada telah mengizinkan penggunaan mata uang digital sebagai alat pembayaran pada transaksi digital di internet. Kanada tidak menganggap cryptocurrency sebagai mata uang yang sah, karena hingga saat ini Kanada masih hanya menganggap uang kertas dan koin yang dikeluarkan oleh Bank of Canada sebagai alat pembayaran yang sah. Mata uang digital dianggap sebagai komoditas dan harus tunduk pada undang-undang pajak dan penghasilan (Al-Shikarchy et al, 2017). Dengan adanya pengakuan crypto sebagai komoditi maka mata uang digital akan tunduk kepada seluruh aturan pajak penghasilan dengan nilai pasar yang wajar dari setiap barang dan jasa yang dibeli menggunakan mata uang digital. Hal ini menggambarkan bahwa setiap barang dan jasa yang dibeli dengan menggunakan mata uang digital harus dimasukan kedalam pendapatan penjual untuk tujuan pajak.

f. Norwegia \& Swedia

Norwegia sebagai negara maju di Eropa dan menjadi negara paling nontunai di dunia dengan hanya terdapat $4 \%$ transaksi pembayaran yang dilakukan dengan menggunakan uang kertas dan koin. Norwegia telah mengakui Bitcoin sebagai komoditas asset yang harus dikenakan pajak tapi tidak menganggapnya sebagai mata uang (Mandelli, 2017). Finanstilsynet sebagai otoritas pengawas keuangan Norwegia menerbitkan pernyataan terkait perlindungan konsumen investor crypto, seluruh perusahaan yang bergerak pada platform crypto diharuskan untuk melaporkan kepada Finanstilsynet untuk mencegah terjadinya pencucian uang. Finanstilsynet sangat fokus terhadap tingkat volatilitas crypto dan adanya kerentanan penipuan yang dapat merugikan investor. Untuk itu Finanstilsynet menyarankan kepada siapapun yang ingin berinvestasi pada pasar crypto agar berhati-hati dan memahami risiko yang dapat timbul serta kepada konsumen agar tidak berinvestasi lebih dari yang mereka mampu.

Swedia juga sama seperti halnya Norwegia dan negara lainnya di Eropa, mengakui Bitcoin sebagai alat pembayaran transaksi digital, bahkan Swedia berencana untuk meluncurkan mata uang digitalnya sendiri yang disebut dengan E-Krona. Swedia merupakan salah satu negara Uni Eropa yang tergabung di dalam Kemitraan Blockchain Eropa, yang dipromosikan oleh Komisi Eropa untuk bekerja sama antara negara anggotanya dalam bertukar pikiran dan pengalaman serta keahlian dibidang teknis dan peraturan dalam mempersiapkan peluncuran blockchain diseluruh Eropa pada pasar digital tunggal baik disektor publik maupun swasta. Penempatan teknologi blockchain akan diatur sedemikian rupa agar dapat meningkatkan transparansi dalam setiap transaksi dan efisiensi komunikasi anatara pihak yang terlibat di dalamnya.

\section{g. China}

Saat ini China menjadi negara yang memiliki miner (penambang) Bitcoin terbanyak di dunia (Huang, 2018). Masyarakat China saat ini banyak yang antusias dengan kehadiran mata uang 
digital. Namun pemerintah China telah memutuskan untuk menghentikan industry cryptocurrency dan tidak mengakui secara penuh terhadap Virtual Coin (VC) untuk di perdagangkan dan ICO. Pemerintah pusat China telah mengeluarkan aturan terkait pencegahan risiko keuangan yang berasal dari ICO dengan tujuan melindungi konsumen atau investor (Pilarowsky \& Yue, 2017). Aturan ICO pada dasarnya telah melarang bursa untuk menggunakan virtual coin. Mengkonversi virtual coin ke dalam tender dan menetapkan harga virtual coin. Namun dampaknya adalah banyaknya investor yang memindahkan modalnya ke platform-platform di Hong Kong (Perper, 2018).

China telah melarang institusi untuk tidak menyediakan layanan simpanan, trust atau penjaminan cryptocurrency atau mengelaurkan produk keuangan yang terkait dengan cryptocurrency. Bahkan pada tahun 2017 China telah menutup bursa uang crypto lokal yang menyumbang terhadap 90\% dari perdagangan Bitcoin global. Selain itu juga, pada tahun 2018 pemerintah China telah menutup sebanyak 88 platform perdagangan mata uang crypto dan 85 platform ICO. Kemudian pada tahun 2019 Bank Sentral China harus mengeluarkan pernyataan yang menyatakan akan memblokir semua akses ke semua pertukaran uang crypto domestik maupun asing serta situs ICO. Dengan tujuan untuk menekan semua perdagangan mata uang crypto serta larangan penukaran terhadap mata uang asing.

Sikap pemerintah China ini didasari oleh adanya risiko tinggi dari perdagangan cryprocurrency yang dianggap sebagai mata uang virtual yang tidak didukung oleh nilai nyata dan harganya cenderung memiliki volatilitas yang tinggi serta mudah untuk dimanipulasi. Namun pemerintah China tidak melarang warganya untuk memegang cryptocurrency. Dengan aturan yang ketat dari pemerintah China, telah merubah China yang sebelumnya memiliki julukan sebagai surganya uang crypto mengingat sebagian besar transaksi cryptocurrency dilakukan oleh warga china baik lokal maupun di luar negeri. Namun saat ini julukan tersebut sudah berubah setelah pemerintah China tidak mengakui cryptocurrency sebagai alat pembayaran yang sah dan melarang sistem perbankan untuk menerima dan menyediakan layanan yang relevan. Saat ini tiga badan regulasi China yang terdiri dari Asosiasi Keuangan Internet Nasional China, Asosiasi Perbankan China, dan Asosiasi Pembayaran dan Kliring China terus malakukan pengawasan ketat.

h. India

Pada tahun 2018 menetri keuangan India telah mengayatakan bahwa Bitcoin bukan sebagai mata uang India dan legal tender karena tidak memiliki atribut fisik sehingga tidak sama dengan mata uang atau koin yang resmi dan sah diterbitkan oleh Otoritas Reserve Bank of India sehingga tidak dapat dijadikan alat tukar. Hal tersebut akan berdampak kepada kontrol mata uang yang ketat menjadi tidak efektif (Nupur, 2018). India menetapkan bahwa pertumbuhan modal dilihat dari 
Prosiding The 1st National Conference on Applied Business, Education, \& Technology (NCABET)"

Unversitas Bina Bangsa 2021

DOI Article : 10.46306/ncabet.v1i1.22

asset akan dianggap sebagai keuntungan modal sehingga departemen pajak dan penghasilan, sekuritas serta dewan India dan kementrian keuangan telah melakukan rincian mendalam terkait dengan transaksi crypto (Jain \& Kumar, 2018). Saat ini India telah melarang penggunaan cryptocurrency sebagai asset oleh bisnis dan lembaga keuangan dan konversi mata uang India ke cryptocurrency merupakan Tindakan illegal.

Pemerintah India bahkan telah menyiapkan undang-undang yang ketat terkait cryptocurrency termasuk Bitcoin, aturan yang keras telah disiapkan oleh Pemerintah India terhadap pemegang dan penambang cryptocurrency dan untuk kedepannya Pemerintah akan meminta kepada pemilik crypto untuk menjual asetnya selama enam bulan kedepan setelah undang-undang di sahkan. Hukuman telah dibuatkan bagi yang tidak mengikuti aturan tersebut dengan hukuman terberat adalah penjara hingga 10 tahun serta denda berat. Kondisi saat ini ternyata masyarakat India masih sangat mecintai virtual coin, hal ini dibuktikan dengan meningkatnya pendaftaran pengguna virual coin hingga 30 kali lipat, bahkan Unocoin yang menjadi bursa tertua di india telah mendapatkan pendatang baru sebanyak 20 ribu.

i. Turki

Pemerintah Turki saat ini telah mendefinisikan crypto sebagai asset nonmoneter dan melarang cryptocurrency sebagai bentuk pembayaran. Menteri Keuangan Turki menginstruksikan kepada Badan Kejahatan dan Investigasi Keuangan (MASAK) untuk mengawasi transaksi crypto di atas 10.000 Lira Turki (US\$ 1.200). Turki pernah mengalami kasus penipuan bermodus mata uang crypto yang dilakukan oleh Perusahaan Thodex yang dimiliki oleh Faruk Fatih Ozer, yang menyebabkan sekitar 391.000 nasabahnya menjadi korban. Dengan total kerugian yang mencapai US\$ 2 miliar atau sekitar Rp. 28,9 triliun. Kasus tersebut bertepatan dengan keputusan Bank Sentral Turki untuk melarang penggunaan mata uang dan asset digital sebagai alat pembayaran mulai pada tanggal 30 April 2021, kasus penipuan ini menjadi yang terbesar dalam sejarah Turki.

Bank Sentral turki telah menargetkan orang dan perusahaan yang mendanai kegiatan illegal atau memfasilitasi pencucian uang dengan menggunakan mata uang crypto. Saat ini MASAK memiliki otoritas penuh untuk melakukan audit terhadap transaksi crypto. Seluruh platform perdagangan crypto diwajibkan untuk membagikan informasi pengguna aktif mereka kepada MASAK dan Platform harus bertanggung jawab terhadap terhadap aktivitas yang mencurigakan pada platform mereka serta wajib memberikan informasi kepada MASAK (Dinanto, 2021). Saat ini pemerintah telah bekerja sama dengan Badan Regulasi dan Pengawasan Perbankan, Badan Pasar Modal dan Administrasi Pendapatan di bawah Kepresidenan dan Wakil Menteri serta para ahli dibidang crypto untuk menyiapakan regulasi yang akan diserahkan kepada Presiden Turki. 
Semua peraturan yang jelas dibutuhkan oleh Pemerintah Turki untuk mengatur sistem perpajakan yang adil dan menghindari korban seperti yang sebelumnya pernah terjadi.

j. Indonesia

Bank Indonesia sebagai Bank Sentral di Indonesia telah menegaskan bahwasanya cryptocurrency Bitcoin serta mata uang virtual lainnya adalah bukan sebagai alat transaksi yang sah. Seluruh transaksi pembayaran di Indonesia harus menggunakan Rupiah sesuai dengan Undang-Undang Nomor 7 Tahun 2011 tentang mata uang. Dan juga kaitannya dengan transaksi dengan menggunakan cryptocurrency mengingat mata uang virtual tidak sesuai dengan UndangUndang Nomor 3 Tahun 2011 yang berhubungan dengan transfer dana karena tidak mendapatkan izin dari Bank Indonesia (Wicaksono, 2018).

Bank Indonesai menilai bahwa mata uang crypto memiliki tingkat risiko yang sangat besar terhadap para spekulan, sebab tidak adanya otoritas yang bertanggung jawab serta tidak adanya administrasi secara resmi yang ketat dan mengikat serta tidak adanya dasr regulasi yang melindungi harga nilai tukar mata uang virtual dalam perdagangan yang cenderung berfluktuatif. Namun saat ini pemerintah telah secara resmi mengizinkan cryptocurrency sebanyak 229 jenis di bursa berjangka dibawah pengawasan Badan Pengawas Perdagangan Berjangka Komoditi (Bappetbti).

Penetapan jenis cryptocurrency yang diperbolehkan didasarkan kepada dua pendekatan. Yang pertama adalah pendekatan yuridis dengan mempertimbangkan peringkat terhadap 500 Coin Market Cap atau CMC dan yang kedua adalah pendekatan menggunakan penilaian analisis hierarki (AHP) dengan memastikan aspek keamanan, profil tim dan anggota tim yang mengembangkan crypto, tata cara pengelolaan blockchain, skalabilitas sistem blockchain, roadmap yang menjelaskan rencana pembangunan sistem blockchain yang dapat diverifikasi pencapaiannya dan nilai standar 6,5. Sehingga Bappebti melakukan delisting terhadap jenis asset crypto yang berada di luar 229 crypto yang diakui di Indonesai.

Bappebti dan OJK sama-sama lembaga negara yang berkaitan dengan pengawasan sektor keuangan sehingga seringkali memiliki peran yang bersinggungan. OJK memiliki tugas, kewenangan dan fungsi untuk mengatur, mengawasi dan melakukan pemerikasaan serta penyidikan terkait sektor jasa keuangan seperti pasar modal, perbankan dan penyedia jasa keuangan yang bukan Bank. Sedangkan Bappebti lebih fokus terhadap pengawasan dan pengaturan kegiatan perdagangan berjangka seperti trading Forex, investasi dan lain sebagainya. Seperti komoditi primer non-keuangan hasil pertaniang, pertambangan dan energi, dan produk non-primer keuangan seperti obligasi, valuta asing, suku bunga dan asset crypto (Fadlansyah, 2021). Hingga saat ini Bappebti telah mengeluarkan izin terhadap 13 perusahaan pedagang asset 
kripto atau biasa disebut broker asset crypto antara lain; PT. Indodax Nasional Indonesia (INDODAX), PT Crypto Indonesia Berkat (TOKOCRYPTO), PT. Zipmex Exchange Indonesia (ZIPMEX), PT. Indonesai Digital Exchange (IDEX), PT. Pintu Kemana Saja (PINTU), PT. Luno Indonesia LTD (LUNO), PT. Cipta Koin Digital (KOINKU), PT. Tiga Inti Utama, PT. Upbit Exchange Indonesia, PT. Bursa Cripto Prima, PT. Rekeningku Dotcom Indonesia, PT. Trinitri Investama Berkat dan PT. Plutonext Digital Aset (Fauzia, 2021).

k. Rusia

Pemerintah Rusia telah mengeluarkan undang-undang terkait dengan mata uang crypto yang dikeluarkan pada bulan Januari 2021. Pemerintah Rusia tidak melarang warganya untuk membeli dan memperdagangkan mata uang crypto namun pemerintah Rusia tidak mengakui crypto sebaga mata uang yang sah di negaranya, mengingat mata uang yang sah di Rusia yang dikeluarkan oleh Bank Sentral adalah Rubel. Pada bulan Mei 2021 anggota parlemen Rusia sedang mengkaji amandemen guna memungkinkan pembayaran crypto sebagai media kontrak.

Gubernur Bank Sentral Rusia telah menyatakan bahwasanya perekonomian akan bergerak secara online sehingga mata uang digital akan menjadi masa depan sistem keuangan. Hampir seluruh orang menggunakan mata uang digital dan Bank Sentral dapat mengisi celah tersebut. Pada bulan Oktober, Rusia akan menyiapkan proposal riset terkai dengan Rubel Digital, tentunya ini merupakan mata uang resmi Rusia yang hanya berubah menjadi digital karena harga 1 Ruber Digital sama dengan 1 Rubel tunai. Uji coba secara resmi akan dilakukan pada tahun 2022. Hal ini telah menimbulkan kekawatiran karena jika setiap Bank Sentral mengeluarkan sistemnya sendiri menggunakan sistem standar teknologi lokal maka yang akan terjadi adalah sangat sulit untuk membuat interkoneksi antara sistem tersebut dengan sistem yang memfasilitasi semua pembayaran lintas batas (CNBC, 2021)

1. El Savador

El Savador merupakan negara bekas jajahan Spanyol dan negara pertama di dunia yang melegalkan Bitcoin sebagai mata uang yang sah di negaranya. Kebijakan ini merupakan eksperimen moneter yang radikal yang dapat menimbulkan risiko ekonomi. El Savador sendiri telah melakukan pembelian Bitcoin sebanyak 550 BTC sehingga nantinya terdapat dua alat pembayaran yang sah di El Savador yaitu dollar AS dan Bitcoin. Demo besar-besaran telah terjadi pada pertengah September tahun ini dimana banyak masyarakat yang turun ke jalan dan melakukan pengrusakan terhadap ATM Bitcoin yang sebelumnya telah dipicu oleh antipati masyarakat terhadap pemerintah saat ini, dimana masyarakat El Savador menganggap Presiden yang berkuasa saat ini sebagai diktator. 
Banyak pakar dan regulator ekonomi yang kawatir dengan kebiajakn yang diambil oleh pemerintah El Savador mengingat mata uang crypto memiliki fluktuasi yang sangat tinggi. Hal tersebut dikawatirkan akan berdampak kepada inflasi harga di negara tersebut, terlebih negara tersebut memiliki tingkat kemiskinan dan pengangguran yang tinggi, disisi lain pemerintah perlu mempertimbangkan kebijakan lainnya yang melindungi investor dan konsumen. Penggunaan Bitcoin sebagai alat transaksi bakal mempengaruhi pelaku usaha lokal, investasi global dan kehidupan sehari-hari penduduk El Savador. Terlebih tanpa adanya kesiapan regulasi yang matang bahkan terkesan berantakan yang mengatur tentang peluncuran Bitcoin sebagai alat pembayaran yang sah.

Banyak lembaga keuangan global yang menganggap kebijakan El Savador dapat membahayakan negaranya sendiri, mulai dari Bank-Bank besar hingga kepada lembaga pemeringkat mengatakan undang-undang tersebut dapat membahayakan proses negosiasi pinjaman dengan IMF, merigikan perusahaan asuransi lokal, dan bahkan dapat melemahkan jaringan Bitcoin. Hal negatif lainnya yang dikawatirkan adalah dapat meningkatnya kejahatan pencucian uang yang dilakukan oleh para sindikat teroris, padahal di negara tersebut tingkat korupsinya masih sangat tinggi (Andriyanto, 2021).

Hasil jejak pendapat terhadap warganya, didapatkan sebanyak $75 \%$ penduduk El Savador keberatan dengan undang-undang Bitcoin tersebut. Meskipun sudah memasuki tahapan akhir, namun pemerintah El Savador masih harus memastikan proses transisi transaksi dengan Bitcoin dapat berjalan dengan lancar. Terlebih Presiden El Savador mewajibkan seluruh pelaku usaha untuk menerima transaksi dengan Bitcoin, namun sayangnya tidak semua pengusaha mengenal teknologi dan hal tersebut yang akan menjadi batu sandungan.

\section{KESIMPULAN}

Kemajuan teknologi telah mendorong penggunaan blockchain sebagai platform cryptocurrency yang desentralisasi dengan sistem peer-to-peer. Hal tersebut telah menimbulkan banyak peluang namun juga menimbulkan risiko. Kecepatan transaksi, kemudahan melakukan transaksi, sistem privatisasi yang terjaga dengan baik, keamanan dan biaya yang murah serta dapat menjadi asset dalam jangka penjang menjadi peluang keuntungan cryptocurrency menjadi semakin banyak diminati oleh masyarakat diseluruh dunia. Namun risiko terhadap adanya pencucian uang, pendanaan teroris dengan menggunakan crypto, peretasan dan skema ICO yang berpotensi merugikan investor menjadi risiko yang harus diatur dengan regulasi yang jelas.

Kemunculan cryptocurrency mendorong terjadinya disrupsi secara besar-besaran pada sektor finansial diseluruh negara. Perbedaan masing-masing negara dalam membuat kebijakan terkait 
Prosiding The 1st National Conference on Applied Business, Education, \& Technology (NCABET)"

Unversitas Bina Bangsa 2021

DOI Article : 10.46306/ncabet.v1i1.22

dengan cryptocurrency didasarkan kepada tujuan keamanan negara dan juga perlindungan terhadap konsumen serta investor serta analisis kebijakan ekonominya masing-masing. Namun disisi lain terdapat peluang yang dapat digali khususnya bagi perputaran modal dan investasi bagi negara yang mampu memformulasikan kebijakan yang bersifat win-win solution agar mampu memanfaatkan peluang secara maksimal namun juga terhindar dari risiko yang bisa berakibat fatal.

Mayoritas negara di dunia saat ini mengakui cryptocurrency sebagai alat tukar dalam melakukan transaksi digital namun tidak mengakui sebagai mata uang yang sah. Beberapa negara bahkan bereaksi keras dengan melarang seluruh kegiatan cryptocurrency di negaranya dan hanya terdapat satu negara yaitu El Savador yang berani menggunakan cryptocurrency Bitcoin sebagai mata uang negaranya selain menggunakan mata uang dollar AS. Namun prerjalanan menuju penggunaan cryptocurrency di El Savador tidak berjalan mulus, mengingat banyak faktor yang harus dipertimbangkan dan juga regulasi yang jelas, terlebih jika salah mengambil kebijakan maka akan berdampak terhadap terjadinya inflasi dan merugikan penduduknya.

Penelitian ini masih memiliki kekurangan, seperti terbatasnya jumlah sampel Negara yang dijadikan sebagai acuan regulasi terkait cryptocurrency. Keterbatasan pada data fluktuasi cryptocurrency dimana peneliti hanya menggunakan data pada penutupan akhir tahum, namun kenyataannya fluktuasi cryptocurrency berfluktuasi sangat cepat dalam hitungan jam dan menit. Penelitian ini belum membahas apakah ada keterkaitannya antara pengaruh cryptocurrency terhadap inflasi pada suatu negara. Sehingga dengan kekurangan ini akan menjadi riset gap bagi peneliti selanjutnya untuk menambahkan variabel dan fokus baru lainnya secara lebih mendalam dan komperhensif.

\section{UCAPAN TERIMA KASIH}

Penulis mengucapkan terima kasih yang sebesar besarnya kepada kedua orang tua, yang telah membesarkan dan mendidik penulis. Tidak lupa juga ucapan terima kasih kepada Prof. Masyhudzulhak Djamil, Prof. Mudrik Alaydrus, Prof. Pantja Djati, Prof. Apollo Daito, Prof. Ngadion Surip dan Prof. Suparmoko selaku guru, inspirator dan panutan bagi penulis. Serta kepada seluruh Tim Panitia $1^{\text {st }}$ National Conference on Applied Business Education \& Technology yang telah menginisiasi acara. Ucapan terima kasih khusus kepada Bapak Dr. Furtasan Ali Yusuf selaku Rektor UNIBA yang selalu mendorong kami untuk selalu berinovasi dan produktif dalam mengembangkan ilmu pengetahuan dan teknologi dalam mewujudkan Merdeka Belajar-Kampus Merdeka menuju Technopreneurship University.

\section{DAFTAR PUSTAKA}


Ahlstrom, D. 2010. Innovation and Growth: How Business Contributes to Society. The Academy of Management Perspective. 24. 11-24.

Al-Shikarchy, Mariam, Baum, S., and Gheorghiu, L. 2017. Gowling WLG, Canadian Taxation of Cryptocurrency: So Far. Lexology. Available online: https://www.lexology.com/library/detail.aspx?g=6283077e-9d32-4531-81a5-56355fa54f47 (accessed on 23 September 2021).

Andriyanto, H. 2021. Kenapa El Savador Pakai Bitcoin? Apa Kabarnya Sekarang?. Available online: https://www.beritasatu.com/ekonomi/827537/kenapa-el-salvador-pakai-bitcoin-apakabarnya-sekarang (accessed on 19 September 2021)

Anupam, Suprita. 2018. Who Is Amit Bhardwaj? The Real Story behind \$300 Mn Bitcoin Ponzi Schemesand More. Available online: https://inc42.com/buzz/who-is-amit-bhardwaj-the-realstory-behind-300-mnbitcoin-ponzi-schemes/ (accessed on 22 September 2021).

Azizah, A.S.N., \& Irfan. 2020. Fenomena Cryptocurrency dalam Perspektif Hukum Islam. Shautuna Jurnal Ilmiah Mahasiswa Perbandingan Mahzab. 1(1). 62-80.

Bacao, P., Duarte, A.P., Sebastiao, H., \& Redzepagic, S. 2018. Information Transmission Between Cryptocurrencies: Does Bitcoin Rule the Cryptocurrency World? Scientific Annals of Economics and Business. 65(2). 97-117.

Bauer, S., and Ahmad, I. 2017. The Lawyers daily. Available online: https://www.wolfelawyers.com/resources/Cryptocurrency-andCybersecurity---TheImplications---The-Lawyer\%27s-Daily.pdf (accessed on 21 September 2021).

Bouri, E., Gupta, R., Lau, C.K.M., Roubaud, D., \& Wang, S. 2018. Bitcoin and Global Financial Stress: A Copula-Based Approach to Dependence and Causality in the Qualtiles, The Quarterly Review of Economics and Finance. 69. 297-307.

Chapron, G. 2017. The environment Needs Cryptogovernance. Nature Bews. 545(7655)/ 403-405.

Cumming, D.J., Johan, S., Pant, A. 2019. Regulation of the Crypto-Economy: Managing Risks, Challenges, and Regulatory Uncertainity. Journal of Risk and Financial Management. 12. 126. 1-14. doi:10.3390/jrfm12030126

CNBC. 2021. Rusia Beri Sinyal Keluarkan Mata Uang Digital Bukan Kripto. Available online: https://www.cnbcindonesia.com/market/20210603132452-17-250314/rusia-beri-sinyalkeluarkan-mata-uang-digital-bukan-kripto (accessed on 18 September 2021)

Dale, B. 2016. The DAO: How the employee less Company has Already Made a Boatload of Money. Available online. http://observer.com/2016/05/dao-decentralized-autonomous-organizations/ (accessed on 20 September 2021)

Databooks. 2021. 4.501 Jenis Mata Uang Kripto Beredar Hingga Februari 2021. Available online: 4.501 Jenis Mata Uang Kripto Beredar hingga Februari 2021
Databoks (katadata.co.id) (accessed on 22 September 2021)

Dinanto. 2021. Transaksi Crypto di atas \$1.200 Langsung dilacak Pemerintah. Available online: https://kabarcoin.com/transaksi-crypto-diatas-1-200-langsung-dilacak-pemerintah/ (accessed on 17 September 2021) 
Fadlansayh, A.Z. 2021. Apa Itu Bappebbti? Apa Fungsi dan Bedanya Dengan OJK. Available online: https://www.gicindonesia.com/jurnal/artikel/bappebti/ (accessed on 20 September 2021)

Fauzia, M. 2021. Daftar 13 Pedagang dan 229 Aset Kripto Terdaftar di Bappebti. Available online: https://money.kompas.com/read/2021/06/17/190000626/daftar-13-pedagang-dan-229-asetkripto-terdaftar-di-bappebti (accessed on 18 September 2021)

Guston, D.H., Fisher, E., Grundwald, A., Owen R., Swierstra, T., \& Van Der Burgs, S. 2014. Responsible Innovation: Motivations for a New Journal. Taylor \& Francis.

Huang, Z. 2018. This Could Be the Beginning of the End of China's Dominance in Bitcoin Mining. Available online: https://qz.com/1172632/chinas-dominance-in-bitcoin-mining-under-threatas-regulators-hit-whereit-hurts-electricity/ (accessed on 24 September 2021).

Internal Revenue Service. 2018. IRS: Criminal Investigation Annual Report 2018. Available online: https://www.irs.gov/pub/irs-utl/2018_irs_criminal_investigation_annual_report.pdf (accessed on 24 September 2021).

Jain, Rupam, and Manoj Kumar. 2018. India Sends Tax Notices to Cryptocurrency Investors as Trading Hits \$3.5 Billion. Available online: https://www.reuters.com/article/us-marketsbitcoin-india-taxes/indiasends-tax-notices-to-cryptocurrency-investors-as-trading-hits-3-5billion-idUSKBN1F8190 (accessed on 24 September 2021).

Lerer, M., \& McGarrigle, C. 2018. Art in the Age of Financial Crisis. Visual Resources. 34(1-2). 112. https://doi.org/10/1080/01973762.2018.1455355

Mandelli, A 2017. Norway's Largest Online Bank Adopts Direct Bitcoin Integration. Available online: $\quad$ https://www.ccn.com/banking-bitcoins-age-norway-bank-adopts-direct-bitcoinintegration/ (accessed on 24 September 2021).

Marian, O. 2013. Are cryptocurrencies super tax havens. Michigan Law Review First Impressions. $112: 38$

Milne, A. 2018. Cryptocurrencies from an Austrian Perspective. In Godart-van der Kroon, A., \& Vonlanthen, P (Eds), Banking and Monetary Policy from the Perspective of Austrian Economics. 223-257. Berlin: Springer International Publishing.

Nakamoto, S. 2008. Bitcoin: A peer-to-peer Electronic Cash System. Satoshi Nakamoto Institute Working Paper. Retrieved from: http://nakamotoinstitute.or/bitcoin/

Nupur, Anand. 2018. Arun Jaitley Has just Killed India’s Cryptocurrency Party. Available online: https://qz.com/india/1195316/budget-2018-busts-bitcoin-arun-jaitley-has-just-killed-indiascryptocurrency-party/ (accessed on 24 September 2021).

Nurul, H. 2021. Harga Bitcoin Hari Ini dan Faktor yang mempengaruhinya. Available online: Harga Bitcoin Hari Ini dan Faktor yang Memengaruhinya (lifepal.co.id) (accessed on 23 September 2021)

Pasar Mata Uang Crypto. 2021. Pasar Mata Uang Crypto: Harga. Koin Crypto. Available online: Pasar Mata Uang Crypto - TradingView (accessed on 24 September 2021). 
Pilarowski, G., \& Lu Yue. 2017. China Bans Initial Coin O erings and Cryptocurrency Trading Platforms, China Regulation Watch (21 September 2017). Available online: http://www.pillarlegalpc.com/en/news/2017/09/21/china-bans-initial-coinofferings-and-cryptocurrency-trading-platforms/ (accessed on 24 September 2021).

Popper, Nathaniel. 2016b. A Hacking of more than $\$ 50$ million dashes hopes in the world of virtual currency. Available online: https://www.nytimes.com/2016/06/18/business/dealbook/hackermay-have- removed-morethan-50-million-from-experimental-cybercurrency-project.html. (accessed on 22 Spetember 2021).

Pemerintah Republik Indonesia. 2011. Undang-Undang Republik Indonesia Nomor 7 Tahun 2011 tentang Mata Uang. Jakarta: Presiden Republik Indonesia.

Pemerintah Republik Indonesia. 2011. Undang-Undang Republik Indonesia Nomor 3 Tahun 2011 tentang Transfer Dana. Jakarta: Presiden Republik Indonesia.

Söderlund, P., \& Kestila-Kekkekonen, E. 2014. Economic Voting in Finland Before and After an Economics Crisis. Acta Politica. 49(4). 395-412.

Spulber, D.F. 2008. Unlocking Technology: Antitrust and Innovation. Journal of Competition Law. 4. 916-66.

Sudzina, F. 2018. Distribution of Foreign Aid in Cryptocurrencies: Initial Considerations. International Advances in Economic Research. 24(4). 387-388.

Tomzack, A. 2018. Cryptocurrency Regulation to Be Welcoming for Business-United Kingdom. Availableonline: $\quad$ https://ethereumworldnews.com/cryptocurrency-regulation-to-bewelcoming-for-business-unitedkingdom/ (accessed on 23 September 2021).

Velazquez, M. 2010. The Report of the Stiglitz Commission: A Summary and Comment. SSRN Scholary Paper ID 2196125.

Westhuizen, C.V.D. 2017. Future Digital Money: The legal status and regulation of Bitcoin in Australia. Working Paper. The university of Notre Dame Australia.

Wicaksono, Y.S. 2019. Keabsahan Transaksi Menggunakan Sistem Cryptocurrency di Indonesia. Fakultas Hukum Universitas 17 Agustus 1945.

Williams-Grut, Oscar. 2018. Only 8\% of ICOs Were Successful Last Year. Available online: https://www.businessinsider.com/how-much-raised-icos-2017-tokendata-2017-2018-1 (accessed on 24 September 2021). 